\title{
CONFUSÃO PATRIMONIAL EM EMPRESAS NA PERSPECTIVA DE CONTADORES E CONTABILISTAS GAÚCHOS
}

\section{ARTIGO ORIGINAL}

VOLTZ, Juliana Poerschke ${ }^{1}$

VOLTZ, Juliana Poerschke. Confusão patrimonial em empresas na perspectiva de contadores e contabilistas gaúchos. Revista Científica Multidisciplinar Núcleo do Conhecimento. Ano 05, Ed. 08, Vol. 01, pp. 134-170. Agosto de 2020. ISSN: 24480959,

acesso: https://www.nucleodoconhecimento.com.br/contabilidade/confusao-

patrimonial

\section{RESUMO}

Este estudo visa contribuir com discussões a respeito de confusão patrimonial nas empresas. O objetivo desta pesquisa é verificar como os contadores e contabilistas do Rio Grande do Sul percebem a confusão patrimonial nas empresas. Foram realizadas discussões sobre as causas, os desafios e as consequências da confusão patrimonial. Sobra a metodologia, trata-se de uma pesquisa mista (quantitativa e qualitativa) e exploratória. Para a coleta de dados, foi aplicado um questionário no Formulário Google, disponibilizado no site do Conselho Regional de Contabilidade do Rio Grande do Sul (CRC/RS) e foram realizadas duas entrevistas semiestruturadas com dois contadores de Porto Alegre. Os resultados evidenciaram que a confusão patrimonial é mais corriqueira nas microempresas e nas empresas de pequeno e médio porte. Esta confusão é oriunda da ausência da gestão, da falta de controle das operações e da utilização dos bens, prejudicando a fidedignidade, a realidade e o resultado financeiro das empresas.

\footnotetext{
${ }^{1}$ Bacharela em Administração pela Faculdade SENAC-RS, graduanda em Ciências Contábeis na Faculdade SENAC-RS.
} 
Palavras-chave: Contadores, confusão patrimonial, controle interno, controladoria, auditoria financeira.

\section{INTRODUÇÃO}

A pesquisa remete ao contexto profissional dos contadores e contabilistas do Rio Grande do Sul e os desafios que encontram com relação à confusão patrimonial nas empresas com as quais trabalham ou já trabalharam. Portanto, neste trabalho foi dado enfoque na diferenciação de pessoa física e jurídica, buscando-se analisar as relações decorrentes da separação entre a propriedade e a gestão. Buscou-se averiguar as experiências e percepções dos profissionais da contabilidade referentes aos os procedimentos, técnicas e rotinas desenvolvidas para lidar com as questões referentes à confusão patrimonial, evidenciar e proteger com segurança e fidelidade o patrimônio das empresas.

Então, o tema deste trabalho refere-se às percepções dos contadores e contabilistas do Rio Grande do Sul sobre o efeito da confusão patrimonial nas empresas e ao controle interno de forma a seguir as normas contábeis, preservando o patrimônio da entidade. A pesquisa foi exploratória qualitativa e quantitativa, realizada por meio de questionários aleatórios e duas entrevistas semiestruturadas com dois contadores do Rio Grande do Sul.

O objetivo da pesquisa foi investigar como os contadores e contabilistas registrados no Conselho Regional de Contabilidade do Rio Grande do Sul percebem a confusão patrimonial nas empresas. Os objetivos específicos foram: verificar a visão dos profissionais da contabilidade sobre as causas da confusão patrimonial nas empresas; investigar os desafios enfrentados pelos contadores e contabilistas com relação à confusão patrimonial em empresas com as quais trabalham; verificar as consequências da confusão patrimonial na gestão financeira das empresas.

A realização do trabalho justifica-se por apresentar contribuições para o esclarecimento do que é, como ocorre a confusão patrimonial e os seus efeitos nas empresas. A pesquisa sobre a confusão patrimonial contribui teoricamente para a 
discussão do seu conceito no contexto atual, para a gestão e para preservação da entidade. Pode despertar o interesse de novos estudantes em pesquisarem o tema, levando em consideração como ponto de partida o estudo sobre a confusão patrimonial.

No que se refere às justificativas práticas, a pesquisa possibilita a reflexão dos contadores e contabilistas ao se depararem com a confusão patrimonial e contribui para o direcionamento de suas ações. Para os empreendedores, a pesquisa fomenta o compromisso com o patrimônio da entidade e auxilia o processo de tomada de decisões. Isto é, os gestores das empresas de pequeno e médio porte podem melhorar a organização da empresa por meio da distinção entre o patrimônio da empresa e o pessoal e, consequentemente, sua performance no mercado.

A seguir são apresentadas as seções do desenvolvimento da pesquisa. Na primeira seção é exposto o referencial teórico, no qual são abordados os principais conceitos e autores relacionados a: empresas e sua classificação de acordo com o porte, seguido as discussões sobre sistema de informação, controle interno, controladoria, auditoria financeira e confusão patrimonial. $\mathrm{Na}$ segunda seção são explicados os caminhos metodológicos seguidos para a realização da pesquisa. Na terceira seção são apresentados e analisados os dados da pesquisa.

Então, são apresentadas as considerações finais. Após, são listadas as referências e os apêndices.

\section{REFERENCIAL TEÓRICO}

Na primeira parte desta seção, é definido o conceito de empresa e uma discussão entre estudiosos sobre o controle interno, seguido por reflexões sobre sistemas de informações, Controladoria e Auditoria financeira. Por fim, apresentado o conceito de confusão patrimonial.

\subsection{EMPRESAS E SUA CLASSIFICAÇÃO EM PORTES}

Para Aquino (2017) apud Mendonça (2000, p. 561), empresa é a 
organização técnico-econômica que se propõe a produzir mediante a combinação dos diversos elementos, natureza, trabalho e capital, bens ou serviços destinados à troca (venda), com a esperança de realizar lucros, correndo os riscos por conta do empresário, isto é, daquele que reúne, coordena e dirige esses elementos sob sua responsabilidade.

Percebe-se, então, que empresa é uma unidade econômica em que é exercida uma atividade, podendo ser serviço ou bem, em troca de lucros. Para definir uma empresa pelo porte, é necessário considerar os critérios de diversos órgãos, conforme apresentados no quadro abaixo:

Quadro 1: Classificação de porte empresarial de acordo com as entidades

\begin{tabular}{|c|c|c|}
\hline \multirow[t]{2}{*}{ Entidade } & \multirow[t]{2}{*}{ Porte } & Critérios \\
\hline & & Por Faturamento \\
\hline \multirow{4}{*}{$\begin{array}{l}\text { Serviço } \\
\text { Brasileiro de } \\
\text { Apoio às Micro e } \\
\text { Pequenas } \\
\text { Empresas } \\
\text { SEBRAE } \\
\text { (PEREIRA, 2019) }\end{array}$} & $\begin{array}{l}\text { Microempreendedor } \\
\text { Individual (MEI) }\end{array}$ & $\begin{array}{l}\text { Faturam até } \mathrm{R} \$ 81 \text { mil por ano. É } \\
\text { enquadrado automaticamente no } \\
\text { Simples Nacional, sendo possível } \\
\text { contratar apenas um colaborador e } \\
\text { pagando o teto da categoria. }\end{array}$ \\
\hline & Microempresa (ME) & $\begin{array}{l}\text { Fatura até } \mathrm{R} \$ 81 \text { mil por ano. } \\
\text { Pode optar entre uma das formas de } \\
\text { tributação (Simples Nacional, Lucro } \\
\text { Real ou Lucro Presumido). }\end{array}$ \\
\hline & $\begin{array}{lr}\text { Empresa } & \text { de } \\
\text { Pequeno } & \text { Porte } \\
\text { (EPP) } & \end{array}$ & $\begin{array}{l}\text { Receita bruta anual inferior ou igual a } \\
\mathrm{R} \$ 360 \text { mil. } \\
\text { Optante entre uma das formas de } \\
\text { tributação (Simples Nacional, Lucro } \\
\text { Real ou Lucro Presumido). }\end{array}$ \\
\hline & $\begin{array}{l}\text { Empresa de médio } \\
\text { porte }\end{array}$ & $\begin{array}{l}\text { Faturamento anual inferior ou igual a } \mathrm{R} \$ \\
4,8 \text { milhões. } \\
\text { Não pode optar pelo Simples Nacional. }\end{array}$ \\
\hline
\end{tabular}




\begin{tabular}{|c|c|c|}
\hline \multirow{3}{*}{ Entidade } & Grandes empresas & $\begin{array}{l}\text { Receita bruta anual acima de } \mathrm{R} \$ 4,8 \\
\text { milhões e não tem limite de } \\
\text { faturamento. }\end{array}$ \\
\hline & & Critérios \\
\hline & Porte & Por Funcionários \\
\hline \multirow{4}{*}{$\begin{array}{l}\text { Instituto } \\
\text { Brasileiro de } \\
\text { Geografia e } \\
\text { Estatística - } \\
\text { IBGE (CUNHA, }\end{array}$} & Microempresa (ME) & $\begin{array}{l}\text { Indústria - até } 19 \text { pessoas ocupadas. } \\
\text { Comércio e Serviços - até } 9 \text { pessoas } \\
\text { ocupadas. }\end{array}$ \\
\hline & $\begin{array}{lr}\text { Empresa } & \text { de } \\
\text { Pequeno } & \text { Porte } \\
\text { (EPP) } & \end{array}$ & $\begin{array}{l}\text { Indústria - de } 20 \text { a } 99 \text { pessoas } \\
\text { ocupadas. } \\
\text { Comércio e Serviços - de } 10 \text { a } 49 \\
\text { pessoas ocupadas. }\end{array}$ \\
\hline & $\begin{array}{l}\text { Empresa de médio } \\
\text { porte }\end{array}$ & $\begin{array}{l}\text { Indústria - de } 100 \text { a } 499 \text { pessoas } \\
\text { ocupadas. } \\
\text { Comércio e Serviços - de } 50 \text { a } 99 \\
\text { pessoas ocupadas. }\end{array}$ \\
\hline & Grandes empresas & $\begin{array}{l}\text { Indústria - De } 500 \text { pessoas ocupadas } \\
\text { ou mais. } \\
\text { Comércio e Serviços - de } 100 \text { pessoas } \\
\text { ocupadas ou mais. }\end{array}$ \\
\hline \multirow[t]{3}{*}{ Entidade } & Porte & $\begin{array}{l}\text { Critérios } \\
\text { Por Faturamento }\end{array}$ \\
\hline & $\begin{array}{l}\text { Grupo I - Empresa } \\
\text { de Grande Porte }\end{array}$ & $\begin{array}{l}\text { Faturamento superior a } \mathrm{R} \$ \\
50.000 .000,00 \\
\text { (cinquenta milhões de } \\
\text { reais). }\end{array}$ \\
\hline & $\begin{array}{l}\text { Grupo II - Empresa } \\
\text { de Grande Porte }\end{array}$ & $\begin{array}{l}\text { Igual ou inferior a } \mathrm{R} \$ 50.000 .000,00 \\
\text { (cinquenta milhões de reais) e superior }\end{array}$ \\
\hline
\end{tabular}




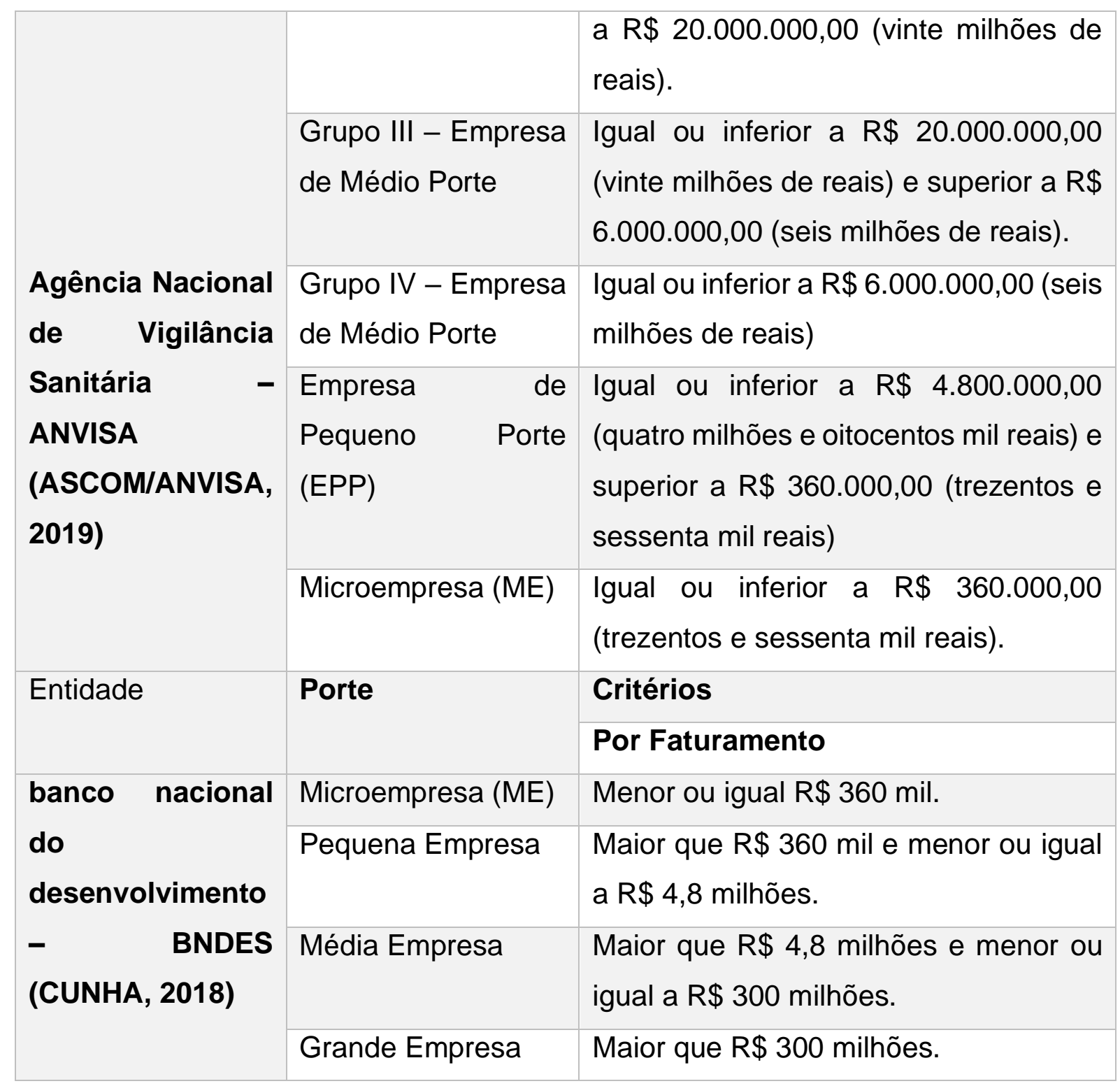

Fonte: Elaborado pela autora.

Ressalta-se que as empresas de pequeno e médio porte possuem importante papel na economia mundial, pois gera diversos empregos e oportunidades. Os dados do Serviço Brasileiro de Apoio às Micro e Pequenas Empresas (SEBRAE) mostram que as empresas familiares de micro e pequeno portes representam $57 \%$ do mercado no Brasil. O Rio Grande do Sul está em 16일 lugar na posição com 54\% do mercado pertencendo a empresa familiar (SEBRAE, 2015). Por isso considerou-se relevante tratar da questão sobre porte das empresas com as quais os contadores e 
contabilistas gaúchos trabalham ou trabalharam em sua trajetória profissional para a discussão sobre a confusão patrimonial.

Em empresas de pequeno e médio porte encontram-se empreendedores que as idealizaram e investiram capital para sua abertura. Evidencia-se, com isso, a importância do profissional da contabilidade. e do conjunto de práticas em conjunto com os outros agentes que dirigem e monitoram (sócios, conselho de administração, diretoria, etc.) uma organização para minimizar conflitos de interesse e aumentar o valor da empresa. Esse conjunto de práticas é chamada de governança corporativa. O Instituto Brasileiro de Governança Corporativa (IBGC), uma organização sem fins lucrativos, contém material que gera e dissemina em seu site sobre as melhores práticas de governança corporativa.

Silva (2005) explica que o conceito de governança existe há mais 50 anos e possui várias definições, citando inclusive a desenvolvida pelo IBGC. O autor faz uma análise do conceito direcionada à tomada de decisões financeira no contexto brasileiro, definindo governança corporativa como "um sistema de práticas visando minimizar os conflitos de interesse entre os agentes da companhia, e, consequentemente, reduzir o custo de capital e aumentar o valor da empresa" (SILVA, 2005, p.16). O aumento do valor da empresa tem como consequência, de acordo com o autor, o aumento do retorno para os acionistas (SILVA, 2005).

Vale ressaltar a mudança da função do contador no Brasil e o papel que este profissional passou a exercer nesse sistema de práticas empresariais. Para Sartori (2018), o perfil do contador mudou, pois este deixou de ser apenas um "guarda-livros" e passou a desempenhar a função de produzir informações uteis aos usuários da contabilidade para a tomada de decisões. Dessa forma, o contador passou a verificar se a gestão está sendo executada corretamente, olhando para os seus controles. 


\subsection{CONTROLE INTERNO}

Os Controles Internos encontram-se nas empresas desde os níveis operacionais até os estratégicos, tendo como objetivos verificar, conferir se a gestão está sendo realizada sem desvio, comparando padrões. Para Attie (1998, p.111),

o controle interno compreende o plano de organização e o conjunto coordenado dos métodos e medidas, adotados pela empresa, para proteger seu patrimônio, verificar a exatidão e a fidedignidade de seus dados contábeis, promover a eficiência operacional e encorajar a adesão à política traçada pela administração.

Para Schmidt e Santos (2006, p. 71), o controle se caracteriza por ser uma "atividade que mede, avalia e indica, caso seja necessário, a correção dos rumos buscando o atendimento dos objetivos e dos planos de negócio". Percebe-se, com isso, que a função do controle está conectada à gestão, correspondendo às necessidades e objetivos das empresas. Portanto, sua prática deve ser contínua, utilizando-se das informações contábeis no processo de gestão, tendo como finalidade assegurar o controle e os resultados da empresa (MÜLER; BEUREN, 2010).

Perez e Hernandez (2011) afirmam que o controle interno se refere às medidas tomadas de forma coordenada dentro de uma empresa para proteger os seus ativos, verificar suas operações e o alinhamento com as diretrizes administrativas da organização. Isto é, o controle interno torna possível que as atividades da empresa sejam eficientes e eficazes (BARBOSA, 2014).

No que se refere à confiabilidade, Almeida (2017, p.53) explica que o controle interno protege os ativos, produzindo dados contábeis confiáveis que auxiliam a administração na condução do empreendimento. Crepaldi e Crepaldi (2017, p.501) ressaltam a importância de analisar a organização dos controles e também na sua execução, pois cada empresa tem que ser examinada, já que cada negócio tem sua peculiaridade. 
Deste modo, o processo do controle interno tem como função regular as atividades exercidas pela organização e padrões pré-estabelecidos. As informações recebidas possibilitam ações corretivas do controle interno.

\subsection{SISTEMA DE INFORMAÇÕES}

O modelo de gestão é constituído por princípios que orientam o gestor na sua atuação (RIOS; PEREIRA ,2018). Para Pereira et al (2019), o modelo de gestão é diretamente influenciado pelo Sistema de Informações, que diz respeito ao conjunto de normas e procedimentos existentes na empresa que envolve recursos financeiros, físicos e humanos. Abrange diversas áreas como a Ciência da Administração, a Economia, a Psicologia, a Estatística e, especificamente, a Contabilidade, cuja principal finalidade é a orientação para a eficácia empresarial (PEREIRA et al, 2019).

Figura 1: O modelo de gestão

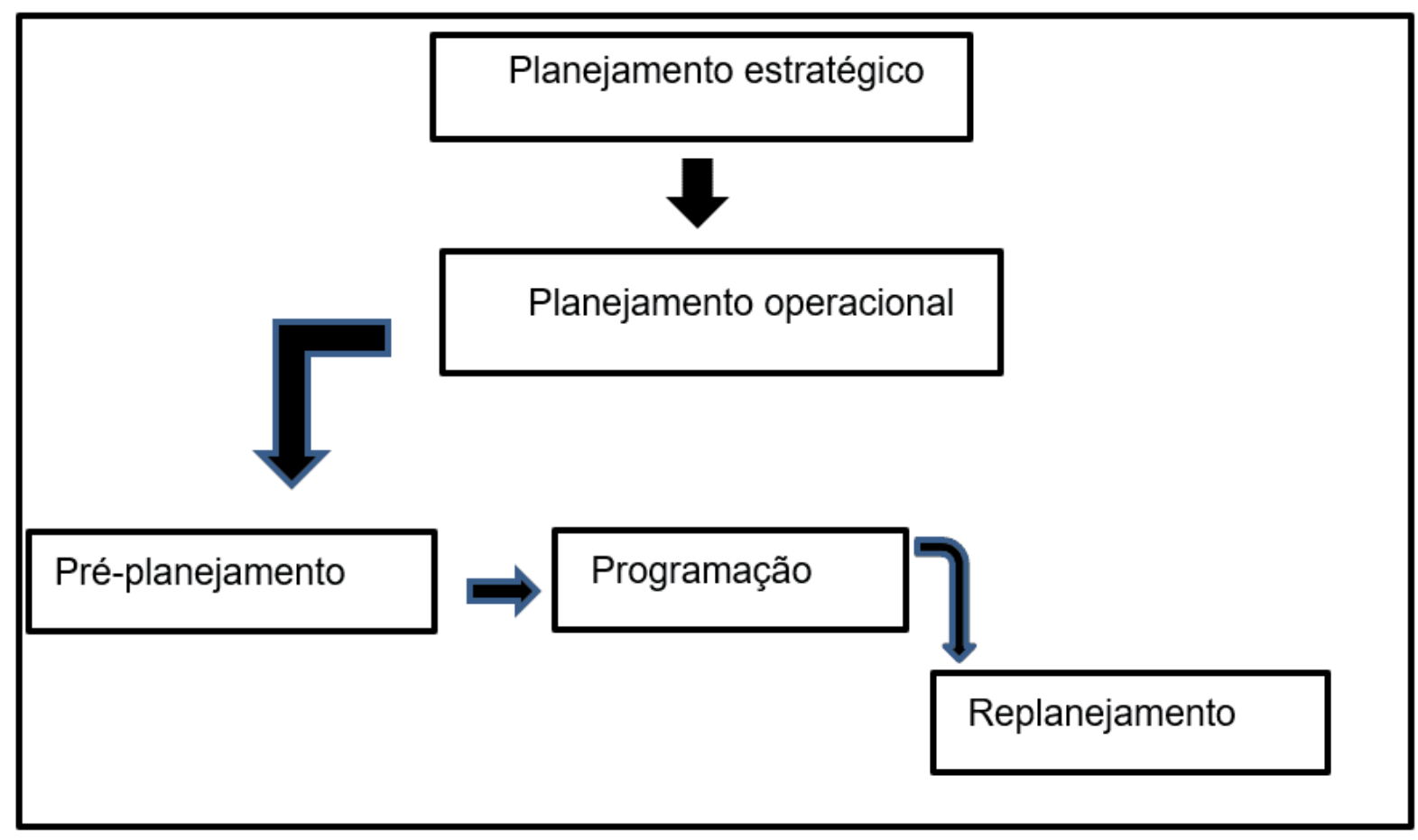

Fonte: Adaptado de Rios e Pereira (2018).

O sistema de controle interno funciona como um filtro que detecta erros ou irregularidades de uma empresa (ALMEIDA, 2017). Dentro do planejamento 
operacional a programação é a uma fase que se relampeja em curto prazo. O replanejamento é devido às alterações do ambiente externo e interno e consiste das necessidades de recursos e análises para executar o plano operacional adotado. (RIOS; PEREIRA, 2018)

\subsubsection{CONTROLADORIA}

A Controladoria pode se referir a controles contábeis e/ou a controles administrativos. Na prática, a divisão entre controles contábeis e administrativos não é muito comum por ambos ficarem sob a égide de um mesmo gestor. Enfim, a Controladoria desenvolve e analisa questões também financeiras (PEREIRA et al, 2019).

Quadro 2: Controles Contábeis x Administrativos

\section{Controles contábeis}

- Sistemas de conferência, aprovação e autorização;

- Segregação de função (pessoas que tem acesso aos registros contábeis não podem custodiar ativos da empresa);

\section{Controle físico sobre ativo;}

- Auditoria interna.

\section{Controles administrativos}

- Análise estatística de lucratividade por linha de produtos;

Controle de qualidade;

- Treinamento de pessoal;

Estudos de tempo e movimentos;

Analise das variações entre os valores orçados e os incorridos;

Controle dos compromissos assumidos, mas ainda não realizados economicamente.

Fonte: Adaptado de Almeida (2017, p. 53).

A função básica da controladoria é monitorar o plano de ação da empresa e os sistemas de informações, fazendo a avaliação coordenada de todos os gestores com 
foco no desempenho global e setorial. A controladoria também apoia os gestores, mas sem o compromisso de obtenção dos resultados, pois cada gestor é responsável pela tomada de decisões de sua área. (RIOS; PEREIRA, 2018)

O sucesso do empreendimento depende do perfeito fluxo de informações internas por meio de um sistema previamente planejado, formado pela estrutura da organização e pelas tecnologias de informação ligadas aos recursos humanos da empresa. Tal sistema permite conhecer o mercado no qual a organização está inserida e auxilia na tomada de decisões (PEREIRA et al, 2019).

\subsection{AUDITORIA FINANCEIRA}

A prática da auditoria contábil surgiu no século XVIII na Inglaterra no contexto das transformações econômicas da Revolução Industrial. Focou inicialmente na fiscalização de tributos, evoluindo posteriormente "para a avaliação das práticas contábeis, a aferição das transações (fatos contábeis) e se complementou como instrumento de validação do ambiente de controle interno praticado pelas entidades auditadas" (PEREZ JUNIOR et al, 2011, p. 18).

Almeida (2017) também afirma que a auditoria surgiu como parte da evolução do sistema capitalista. Para o autor, em razão do desenvolvimento tecnológico e o acirramento da concorrência, foi necessário que as empresas ampliassem suas instalações fabris e administrativas para expandirem no mercado. Para isso, passaram a aprimorar os controles internos com vistas a reduzir os custos, tornando seus produtos e serviços mais competitivos no mercado.

Crepaldi e Crepaldi (2017, p.4) conceituam auditoria como "o levantamento, estudo e avaliação sistemática das transações, procedimentos, operações, rotinas e das financeiras de uma entidade". Para os autores, os procedimentos técnicos da auditoria se destinam à construção de um parecer sobre a adequação das demonstrações contábeis às normas e leis contábeis vigentes, podendo evitar situações de fraudes, desfalques e subornos. 
Segundo Perez Junior et al (2011), há três tipos de auditoria: auditoria externa ou independente, auditoria interna e auditoria fiscal. A auditoria fiscal e exercida, em geral, por servidores públicos concursados: os auditores fiscais. Esses auditores "objetivam verificar a regularidade no recolhimento dos tributos (impostos, taxas e contribuições), por meio da análise das transações realizadas e documentaçãosuporte" (PEREZ JUNIOR et al, 2011, p. 26). O quadro a seguir mostra as diferenças entre auditor externo e auditor interno.

Quadro 3 - Diferenças entre auditor interno e auditor externo

\begin{tabular}{|c|c|}
\hline Auditor Interno & Auditor Externo \\
\hline - É empregado da empresa auditada; & $\begin{array}{l}\text { - Não tem vínculo empregatício com a } \\
\text { empresa auditada; }\end{array}$ \\
\hline - Menor grau de independência; & - Maior grau de independência; \\
\hline $\begin{array}{l}\text { - Executa auditoria contábil e } \\
\text { operacional; }\end{array}$ & - Executa apenas auditoria contábil; \\
\hline $\begin{array}{l}\text { Os principais objetivos são: } \\
\text { Verificar se todas as normas } \\
\text { internas estão sendo seguidas; } \\
\text { Verificar a necessidade de } \\
\text { aprimorar as normas internas } \\
\text { vigentes; } \\
\text { Verificar a necessidade de } \\
\text { novas normas internas; }\end{array}$ & $\begin{array}{l}\text { - O principal objetivo é emitir um parecer } \\
\text { ou opinião sobre as demonstrações } \\
\text { contábeis, no sentido de verificar se estas } \\
\text { refletem adequadamente a posição } \\
\text { patrimonial e financeira, o resultado das } \\
\text { operações, as mutações do patrimônio } \\
\text { líquido e os fluxos de caixa da empresa } \\
\text { examinada. Também, se essas } \\
\text { demonstrações foram elaboradas de } \\
\text { acordo com os princípios. }\end{array}$ \\
\hline $\begin{array}{l}\text { Efetuar auditoria das diversas } \\
\text { áreas das demonstrações contábeis } \\
\text { e em áreas operacionais; }\end{array}$ & \\
\hline
\end{tabular}




\begin{abstract}
- Maior volume de testes (tem maior - Menor volume de testes, já que está tempo na empresa para executar os interessado em erros que individualmente serviços de auditoria). ou cumulativamente possam alterar de maneira substancial as informações das demonstrações contábeis.
\end{abstract}

Fonte: Almeida (2017, p.6).

Cruz, Souza e Junior (2018, p.6), definem auditoria como "o levantamento, estudo e avaliação sistemática das transações, procedimentos, operações, rotinas e das demonstrações financeiras de uma entidade". É exercida por técnicos especializados para salvaguardar o patrimônio da entidade auditada.

A auditoria tem o intuito de analisar as demonstrações financeiras e na elaboração de um parecer sobre a veracidade das mesmas e atestar que elas demonstrem corretamente a situação patrimonial e financeira, o desfecho de suas ações e as origens e aplicações de recursos equivalentes aos períodos examinado, conforme os princípios primordiais da contabilidade, colocados com invariabilidade durante os períodos. (SILVA, 2018)

Cruz e Souza Junior (2018, p.6) definem auditoria de forma semelhante, como "o levantamento, estudo e avaliação sistemática das transações, procedimentos, operações, rotinas e das demonstrações financeiras de uma entidade". A auditoria tem o intuito de analisar as demonstrações financeiras para a elaboração de um parecer sobre a veracidade das mesmas, atestando que elas demonstrem corretamente a situação patrimonial e financeira da empresa, o desfecho de suas ações e as origens e aplicações de recursos equivalentes aos períodos examinado, conforme os princípios primordiais da Contabilidade (SILVA, 2018).

A auditoria contribui para a permanência das organizações no mercado, por auxiliar na detecção de falhas, fraude e riscos que podem comprometer as atividades da gestão. Por meio da auditoria se investiga quais os pontos de melhoria para o empreendimento, emitindo opiniões e sugestões, através de parecer requisitando 
possíveis correções, tendo em vista manter o empreendimento sempre atualizada, agindo de forma proativa para a expansão e o sucesso da organização (PEREIRA et al, 2019).

\subsection{CONFUSÃO PATRIMONIAL}

Confusão Patrimonial é um termo simples na prática. No entanto, rotineiramente podem ser observadas dificuldades na compreensão e no exercício de manter o patrimônio da pessoa física e da pessoa jurídica em campos distintos.

De acordo com a LEI № 13.874, DE 20 DE SETEMBRO DE 2019 (BRASIL, 2019), em seu Art. 50,

Em caso de abuso da personalidade jurídica, caracterizado pelo desvio de finalidade ou pela confusão patrimonial, pode o juiz, a requerimento da parte, ou do Ministério Público quando Ihe couber intervir no processo, desconsiderá-la para que os efeitos de certas e determinadas relações de obrigações sejam estendidos aos bens particulares de administradores ou de sócios da pessoa jurídica beneficiados direta ou indiretamente pelo abuso.

$\S 11^{\circ}$ Para os fins do disposto neste artigo, desvio de finalidade é a utilização da pessoa jurídica com o propósito de lesar credores e para a prática de atos ilícitos de qualquer natureza.

$\S 2^{\circ}$ Entende-se por confusão patrimonial a ausência de separação de fato entre os patrimônios, caracterizada por:

I - cumprimento repetitivo pela sociedade de obrigações do sócio ou do administrador ou vice-versa;

II - transferência de ativos ou de passivos sem efetivas contraprestações, exceto os de valor proporcionalmente insignificante; e

III - outros atos de descumprimento da autonomia patrimonial.

$\S 3^{\circ} \mathrm{O}$ disposto no caput e nos $\S \S 1^{\circ}$ e $2^{\circ}$ deste artigo também se aplica à extensão das obrigações de sócios ou de administradores à pessoa jurídica. 
§ 4ำ A mera existência de grupo econômico sem a presença dos requisitos de que trata 0 caput deste artigo não autoriza a desconsideração da personalidade da pessoa jurídica.

$\S 5$ №̃a constitui desvio de finalidade a mera expansão ou a alteração da finalidade original da atividade econômica específica da pessoa jurídica." (NR)

A Resolução CFC no 750/93 do Conselho Federal de Contabilidade (1993) abordava sete principais princípios da Contabilidade (princípio da entidade, princípio da continuidade, princípio da oportunidade, princípio do registro pelo valor original, princípio da atualização monetária, princípio da competência e princípio da prudência). Segundo a referida Resolução, em seu Art. 4º,

- Princípio da ENTIDADE reconhece o Patrimônio como objeto da Contabilidade e afirma a autonomia patrimonial, a necessidade da diferenciação de um Patrimônio particular no universo dos patrimônios existentes, independentemente de pertencer a uma pessoa, um conjunto de pessoas, uma sociedade ou instituição de qualquer natureza ou finalidade, com ou sem fins lucrativos. Por consequência, nesta acepção, - Patrimônio não se confunde com aqueles dos seus sócios ou proprietários, no caso de sociedade ou instituição (CONSELHO FEDERAL DE CONTABILIDADE, 1993).

Apesar de revogados, os Princípios Contábeis foram diluídos em diversos CPCs (Comitês de Pronunciamentos Contábeis) e continuam a orientar os procedimentos para a elaboração dos demonstrativos contábeis e financeiros. Os princípios contábeis passaram a ser comportados no NBC TG Estrutura Conceitual (Resolução no 1.374/2011) no setor privado e a NBC TSP Estrutura Conceitual no setor público.

O patrimônio de uma empresa deve ser separado do patrimônio dos sócios ou do patrimônio do proprietário. A empresa que não realizar tal separação pode ser penalizada conforme art. 50 Lei no 13.874 (BRASIL, 2019). Pode-se dizer, então, que a utilização do controle interno e da auditoria como ferramentas conferem à gestão a verificação da distinção entre o patrimônio da organização e o patrimônio pessoal. 


\section{CAMINHOS METODOLÓGICOS}

O método de pesquisa conforme Cervo, Bervian e Silva (2007, p. 27) "é a ordem que se deve impor a diferentes processos necessários para atingir certo fim ou um resultado desejado. Na ciência, entende-se por método o conjunto de processos empregados na investigação". Esse conjunto de processos "deve dispor de um instrumental claro, coerente, elaborado, capaz de encaminhar os impasses teóricos para o desafio da prática" (MINAYO, 2008, p.14).

De acordo com Gil (2010, p.17), o método de pesquisa pode ser definido "como um procedimento racional e sistemático que tem como objetivo proporcionar respostas aos problemas que são propostos", ou seja, a pesquisa envolve três elementos chaves: dúvida/problema, método cientifico e resposta/soluções, que são estudados, desenvolvidos com base teórica, com técnicas e métodos científicos. A metodologia de pesquisa é essencial para a compreensão do estudo, para o seu o desenvolvimento e sua análise.

Para este estudo, foi realizada a pesquisa mista (qualitativa e quantitativa), do tipo exploratória. Os dados quantitativos ajudaram a ter um panorama mais geral das percepções dos contadores e contabilistas do Rio Grande do Sul. Os dados qualitativos permitiram examinar os aspectos mais profundos e subjetivos do tema (MORESI, 2003).

Neste trabalho a pesquisa escolhida foi a quali-quanti pois houve a preocupação com a representatividade numérica e com o aprofundamento da compreensão do fenômeno pesquisado. A pesquisa é de caráter exploratório, pois busca uma visão geral que aponta para novas ideias sobre aa problemática da confusão patrimonial nas empresas. Segundo Gil (2008, p. 27) as pesquisas exploratórias

São desenvolvidas com o objetivo de proporcionar visão geral, de tipo aproximativo, acerca de determinado fato. Este tipo de pesquisa é realizado especialmente quando o tema escolhido é pouco explorado e torna-se difícil sobre ele formular hipóteses precisas e operacionalizáveis. 
Foram aplicados questionários por meio do formulário Google a contadores e contabilistas do Rio Grande do Sul para compreender sua percepção sobre as questões que permeiam a confusão patrimonial nas empresas. A coleta de dados foi realizada por meio de um questionário auto aplicado com perguntas abertas, fechadas e dependentes[2], submetido a uma amostra por acessibilidade ou conveniência (em que o pesquisador seleciona os sujeitos a que tem acesso, de forma que representem o universo (GIL, 2008) de contadores e contabilistas registrados no Conselho Regional de Contabilidade do Rio Grande do Sul (CRC-RS). Por meio de contatos profissionais e acadêmicos, foram enviadas aproximadamente 100 mensagens por Whatsapp, solicitando que os contadores e contabilistas acessassem o site do CRC-RS para responder um questionário. Para Gil (2008), um questionário é a técnica de investigação que traduz os objetivos da pesquisa em questões específicas a fim de possibilitar respostas dos pesquisados sobre o tema da pesquisa.

Neste trabalho, foi utilizada a técnica do funil, em que a ordenação das perguntas do questionário se dá por meio da sua relação com a pergunta anterior. Isto é, inicia-se com uma pergunta mais geral sobre a temática, seguida de uma pergunta mais específica, mas relacionada com a primeira, até a pergunta que contenha elementos suficientes para a obtenção de respostas mais precisas sobre o que o pesquisador deseja compreender.

Foi disponibilizado um formulário Google no site do CRC-RS (APÊNDICE A) no dia 19 de maio até o dia 31 de maio para que contadores e contabilistas registrados no Rio Grande do Sul respondessem as questões elaboradas sobre Confusão Patrimonial. O pouco tempo que a estudante dispunha para a realização da análise e entrega do TCC impossibilitou que o formulário ficasse por mais tempo no site do CRC-RS e um maior número de respondentes. Contudo, os sujeitos que responderam as questões possibilitaram a produção de informações importantes sobre o tema estudado.

Para corroborar com as respostas do questionário foram realizadas entrevistas semiestruturadas com dois contadores (APÊNDICE B). A entrevista semiestruturada é a menos estruturada possível e tem o objetivo obter uma "visão mais geral do 
problema pesquisado. (GIL, 2008, p. 111), "o que se pretende com entrevistas deste tipo é a obtenção de uma visão geral do problema pesquisado [...]". Por meio das entrevistas os contadores forneceram relatos de experiência profissional que envolviam confusão patrimonial e explicaram como lidaram com a questão, auxiliando a autora deste trabalho a propor sugestões de trabalhos futuros.

No que se refere à amostra do trabalho, na etapa quantitativa 46 sujeitos registrados no CRC-RS responderam o questionário. De acordo com Deslauriers (1991 apud GERHARDT; SILVEIRA, 2009, p.31), "o objetivo da amostra é de produzir informações aprofundadas e ilustrativas: seja ela pequena ou grande, o que importa é que ela seja capaz de produzir novas informações". Para a etapa qualitativa, foram escolhidos dois contadores acessíveis à autora, que também responderam o questionário. Foram realizadas três entrevistas via Skype, uma no dia 06 de junho de 2020 e outra no dia 07 de junho de 2020. As entrevistas foram gravadas e posteriormente transcritas para análise.

A análise dos dados "é a tentativa de evidenciar as relações existentes entre o fenômeno estudado e outros fatores" (MARKONI; LAKATOS, 2010, p.151). Nesta pesquisa os dados foram analisados por meio da técnica de análise interpretativa. Esta baseia-se nas categorias construídas no próprio trabalho a partir da revisão da literatura selecionada pelo pesquisador. Segundo Triviños (p. 173), a análise interpretativa apoia-se

a) nos resultados alcançados no estudo (respostas aos instrumentos, ideias dos documentos etc.); b) na fundamentação teórica (manejo dos conceitos-chaves das teorias e de outros pontos de vista); c) na experiência pessoal do investigador. o relatório do estudo realizado é um corpo integrado desses três aspectos básicos, de maneira que as denominadas "conclusões" e "recomendações" tradicionalmente apresentadas ao final da exposição surgem em qualquer momento da mesma.

Este trabalho estabeleceu três objetivos específicos: verificar a visão dos profissionais da contabilidade sobre as causas da confusão patrimonial nas empresas; investigar os desafios enfrentados pelos contadores e contabilistas com relação à confusão patrimonial em empresas com as quais trabalham; verificar as consequências da 
confusão patrimonial na gestão financeira das empresas. Esses objetivos, em conjunto com a construção teórica auxiliaram a sistematização da interpretação dos dados coletados.

\section{APRESENTAÇÃO E ANÁLISE DOS DADOS}

A seguir é apresentada a análise dos dados obtidos pela aplicação do questionário, relacionando esses dados com os relatos dos dois entrevistados (que foram também respondentes do questionário), resgatando o referencial teórico e comparando com resultados de outras pesquisas realizadas. Salienta-se que 46 contadores / contabilistas responderam o questionário no Formulário Google.

Preserva-se os nomes das empresas e dos investigados para a proteger a sua imagem, conforme as Diretrizes Éticas da Pesquisa Envolvendo Seres Humanos, nos termos estabelecidos na Resolução CNS № 466/2012, e obedecendo as disposições legais estabelecidas na Constituição Federal Brasileira, artigo 5ํ, incisos X e XIV e no Novo Código Civil, artigo 20. Portanto os entrevistados serão identificados com um e dois.

Gráfico 1: Quantidade de clientes (CNPJ) com os quais os contadores/contabilistas investigados trabalham

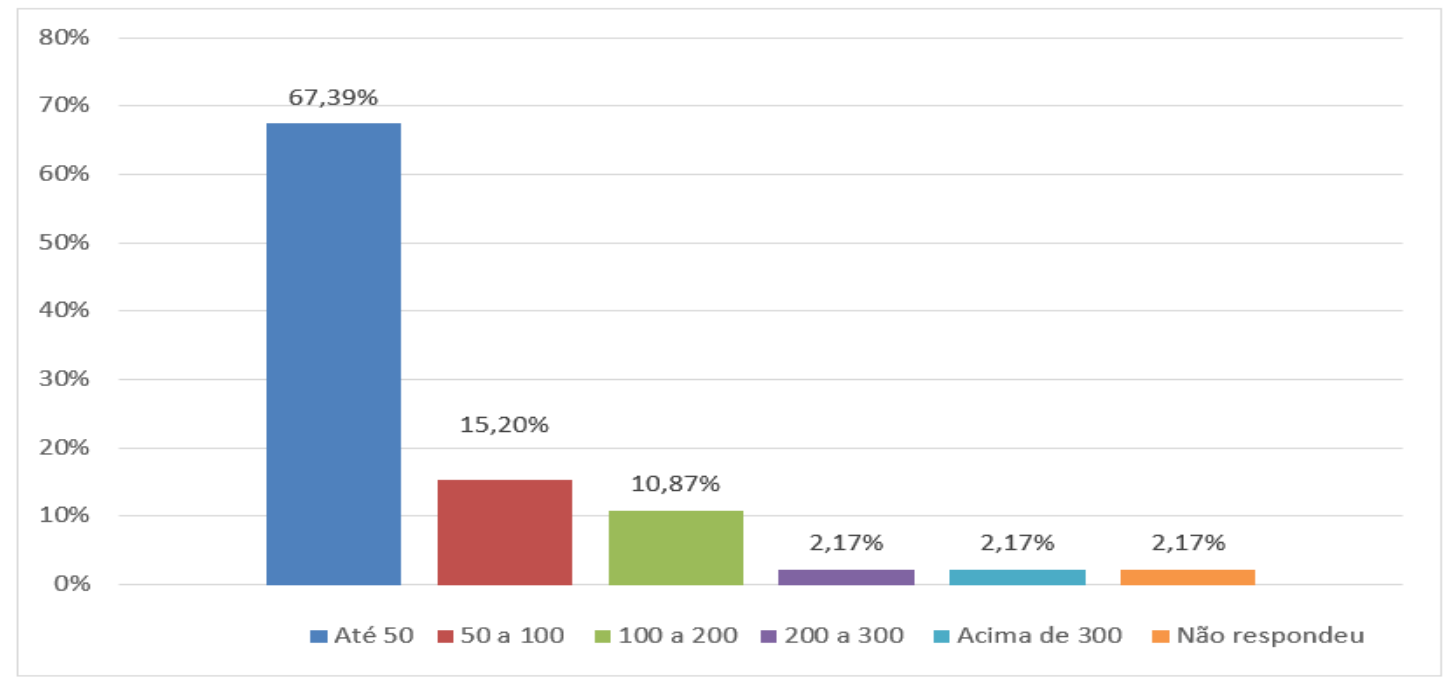

Fonte: Elaborado pela autora 
Dos 46 respondentes do questionário, foram obtidas as seguintes respostas: 31 $(67,39 \%)$ responderam que trabalham com até 50 empresas (CNPJ); sete $(15,20 \%)$ responderam que o intervalo entre 50 e 100 compreende a quantidade de empresas (CNPJ) com as quais trabalham; cinco $(10,87 \%)$ responderam que o intervalo entre 100 e 200 abarca a quantidade de empresas (CNPJ) com as quais trabalham; um $(2,17 \%)$ respondeu que a quantidade de empresas (CNPJ) com as quais trabalha encontra-se no intervalo de 200 a 300; um (2,17\%) respondente afirmou trabalhar com mais de 300 empresas (CNPJ); um $(2,17 \%)$ respondente deixou em branco a questão sobre a quantidade de empresas com as quais trabalha. Percebe-se que a maioria dos profissionais da área contábil trabalha com até cinquenta empresas.

Gráfico 2: Confusão Patrimonial nas empresas com as quais os pesquisados trabalham

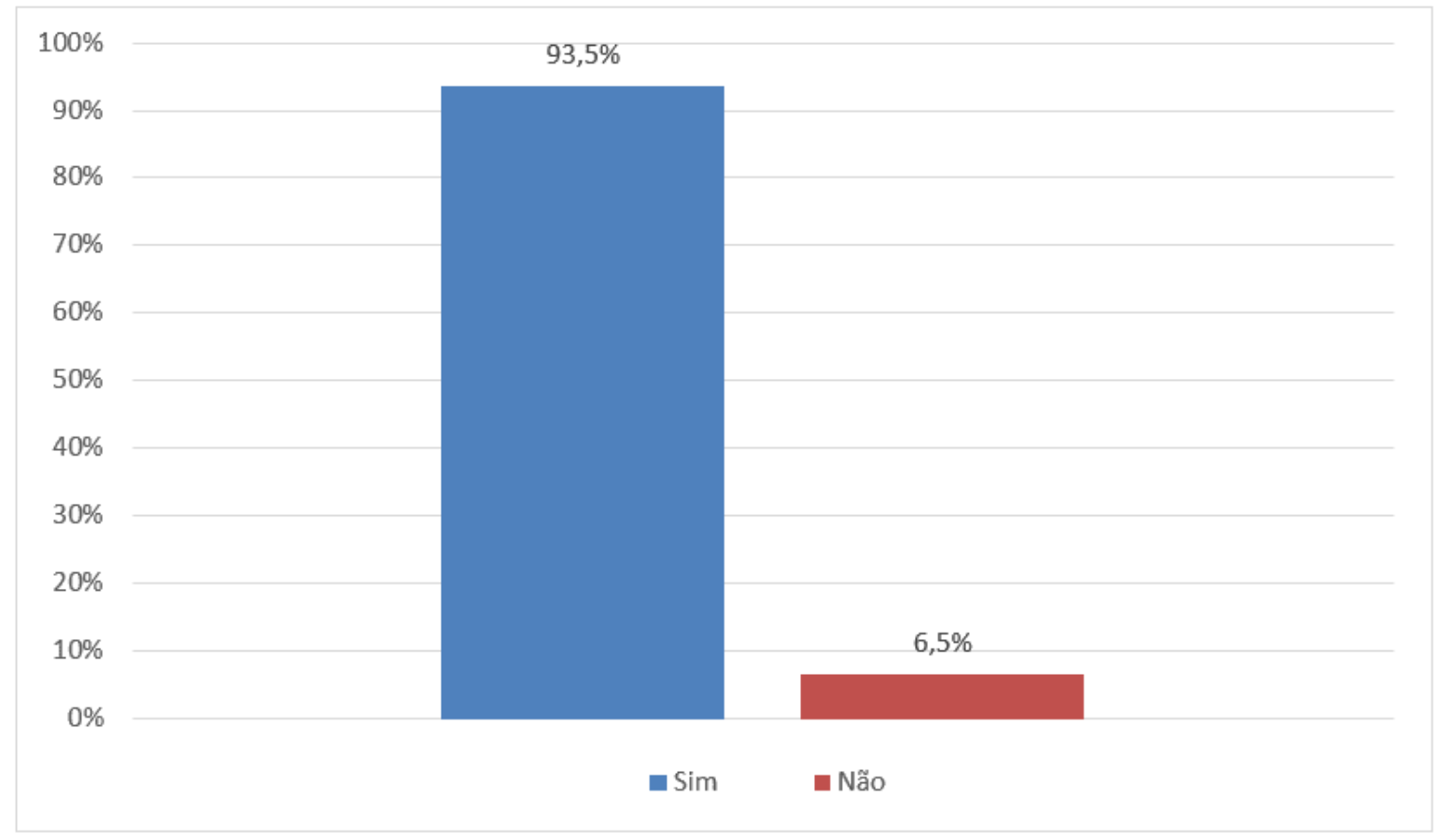

Fonte: Elaborado pela autora

A grande maioria dos contadores e contabilistas que responderam o questionário, 43 $(93,5 \%)$ presenciam a confusão patrimonial, isto é, enfrentam problemas com a distinção entre pessoa física e jurídica nas empresas com as quais trabalham. Notase que apenas três $(6,5 \%)$ respondentes não percebem ou não vivenciam a confusão 
patrimonial nas empresas. Este resultado evidencia a relevância da investigação sobre o tema, por ser uma questão com a qual muitos profissionais da área precisam lidar e pela baixa produção existente.

A autora deste trabalho realizou uma pesquisa na Biblioteca Digital Brasileira de Teses e Dissertações (BDTD) no dia cinco de junho de 2020. Foi buscada a expressão "confusão patrimonial" em todos os campos, retornando apenas sete Teses e Dissertações que continham a expressão em seu texto. Ressalta-se que os trabalhos encontrados são recentes, de forma que a maioria foi produzida nos últimos dez anos (apenas um foi realizado em 2008 e um em 2005). Além disso, apenas um dos trabalhos encontrados refere-se diretamente ao tema, cujo título foi: Confusão patrimonial nas sociedades isoladas e nos grupos societários: caracterização, constatação e tutela dos credores (SCALZILLI, 2014).

Retomo aqui outra questão já desenvolvida neste estudo: a questão jurídica que trata da confusão patrimonial. A lei em questão é a LEI № 13.874, DE 20 DE SETEMBRO DE 2019, em seu Artigo 50 (BRASIL, 2019).

Gráfico 3: Percentual das empresas que apresentam Confusão Patrimonial

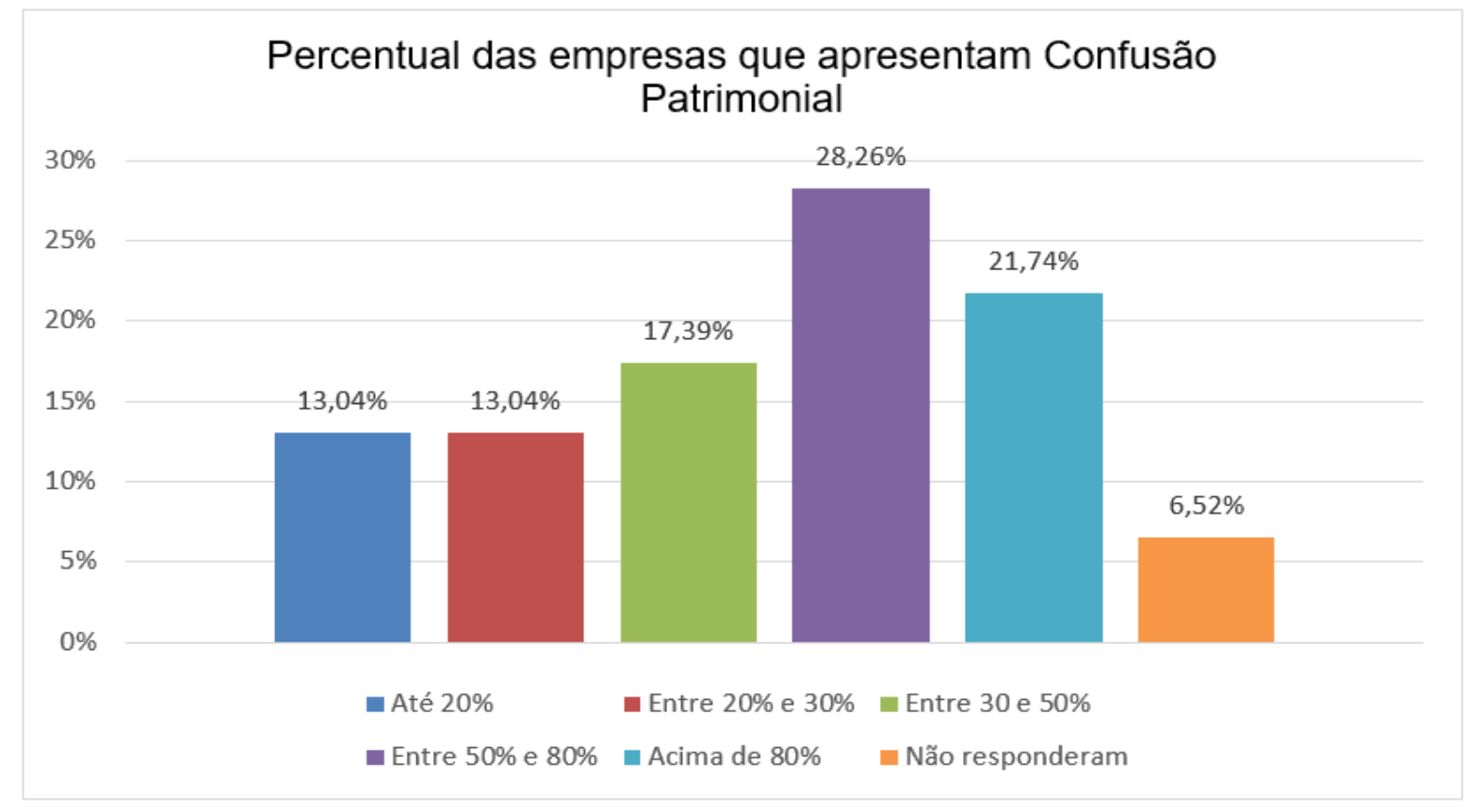

Fonte: Elaborado pela autora 
Dos 46 respondentes do questionário, 43 perceberam confusão patrimonial nas empresas e por isso responderam à questão do percentual de empresas que apresenta a confusão patrimonial. Os três $(6,52 \%)$ que responderam que não percebem ou vivenciam a confusão patrimonial nas empresas nas quais trabalham, não responderam esta questão.

Foram obtidas as seguintes respostas: $13(28,26 \%)$ inquiridos percebem a confusão patrimonial entre $50 \%$ e $80 \%$ das empresas que trabalham; dez $(21,74 \%)$ inquiridos enxergam a confusão patrimoniais acima de $80 \%$ das empresas que trabalham; oito $(17,39 \%)$ inquiridos veem a confusão patrimonial entre $30 \%$ e $50 \%$ das empresas que trabalham; seis (13,04\%) enxergam a confusão patrimonial entre $20 \%$ e $30 \%$ das empresas que trabalham; seis $(13,04 \%)$ percebem a confusão patrimonial até $20 \%$ das empresas em que trabalham.

Contate-se que a maioria $23(56,52 \%)$ respondentes presencia a confusão patrimonial na maioria das empresas das quais trabalham, o que evidencia a importância deste estudo.

Gráfico 4: Porte das empresas que apresentam Confusão Patrimonial

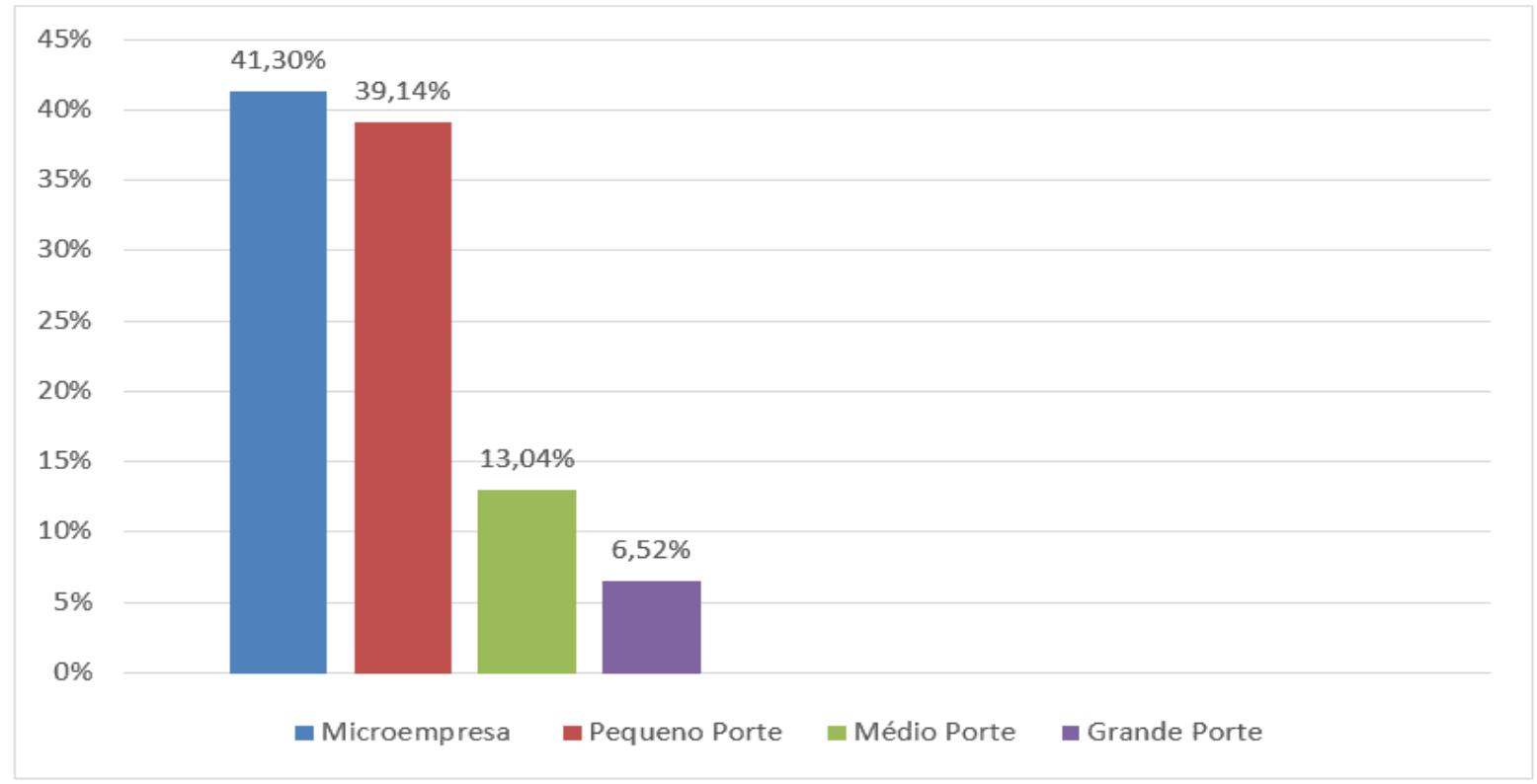

Fonte: Elaborado pela autora 
No que se refere ao porte das empresas que apresentam Confusão Patrimonial, foram obtidas as seguintes respostas: $21(41,30 \%)$ inquiridos percebem a confusão patrimonial nas microempresas; $18(39,14 \%)$ respondente enxergam a confusão patrimonial nas empresas de Pequeno Porte; seis $(13,04 \%)$ percebem a confusão patrimonial nas empresas de Médio Porte; três $(6,52 \%)$ enxergam a confusão patrimonial nas empresas de Grande Porte.

Observa-se que a maioria dos respondentes apontou a predominância da confusão patrimonial nas microempresas e empresas de Pequeno porte. As microempresas e empresas de pequeno porte representam nas últimas décadas a maioria das empresas no Brasil e maiores geradoras de empregos formais. De acordo com o Diário do Comércio (DIÁRIO DO COMÉRCIO, 2020) as micro e pequenas empresas (MPEs) desempenha um papel cada vez mais estratégico na economia brasileira, e hoje já respondem por $30 \%$ do valor adicionado ao Produto Interno Bruto (PIB) brasileiro.

Gráfico 5: Origem da confusão patrimonial nas empresas

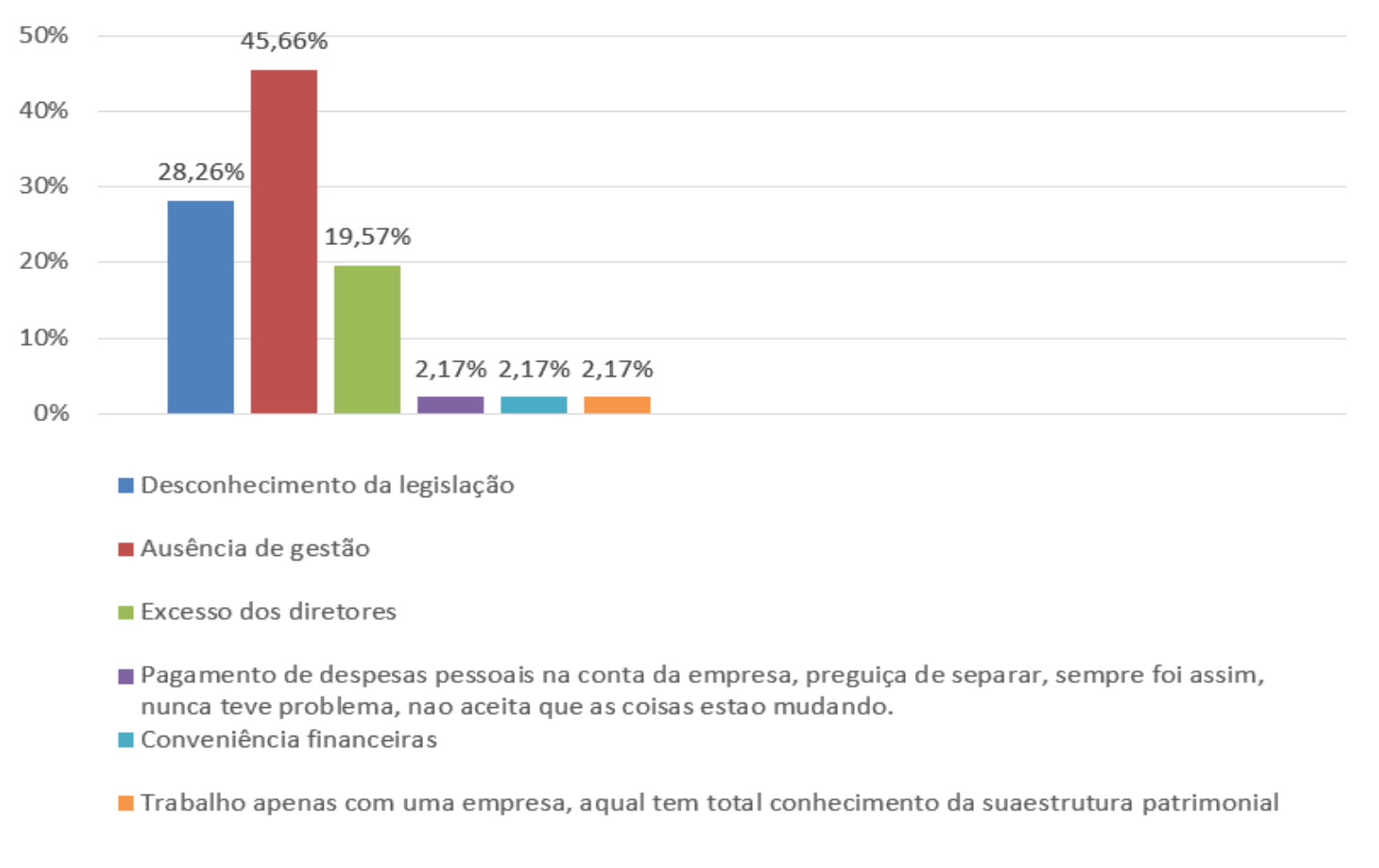

Fonte: Elaborado pela autora 
Quanto à origem da confusão patrimonial nas empresas, foram obtidas as seguintes respostas: $21(45,66 \%)$ responderam que a confusão patrimonial é oriunda da ausência da gestão; $13(28,26 \%)$ responderam que a confusão se origina do desconhecimento dá legislação; nove $(19,57 \%)$ respondentes percebem que a confusão patrimonial se inicia pelo excesso dos diretores; um $(2,17 \%)$ respondente enxerga que a confusão patrimonial origina-se pelo pagamento de despesas pessoais na conta da empresa; um $(2,17 \%)$ respondente vê a confusão patrimonial como conveniente financeiramente; um $(2,17 \%)$ respondente afirma que trabalha com apenas uma empresa, tendo total conhecimento da sua estrutura patrimonial.

A maioria dos respondentes, que equivale a $43(93,48 \%)$, acredita que a confusão patrimonial é oriunda da ausência da gestão, do desconhecimento da legislação e do excesso dos diretores. Isso vai ao encontro dos estudos de Kassai (1997), que ressalta o despreparo dos empreenderes na área administrativa.

Gráfico 6: Desafios Enfrentados com relação à Confusão Patrimonial

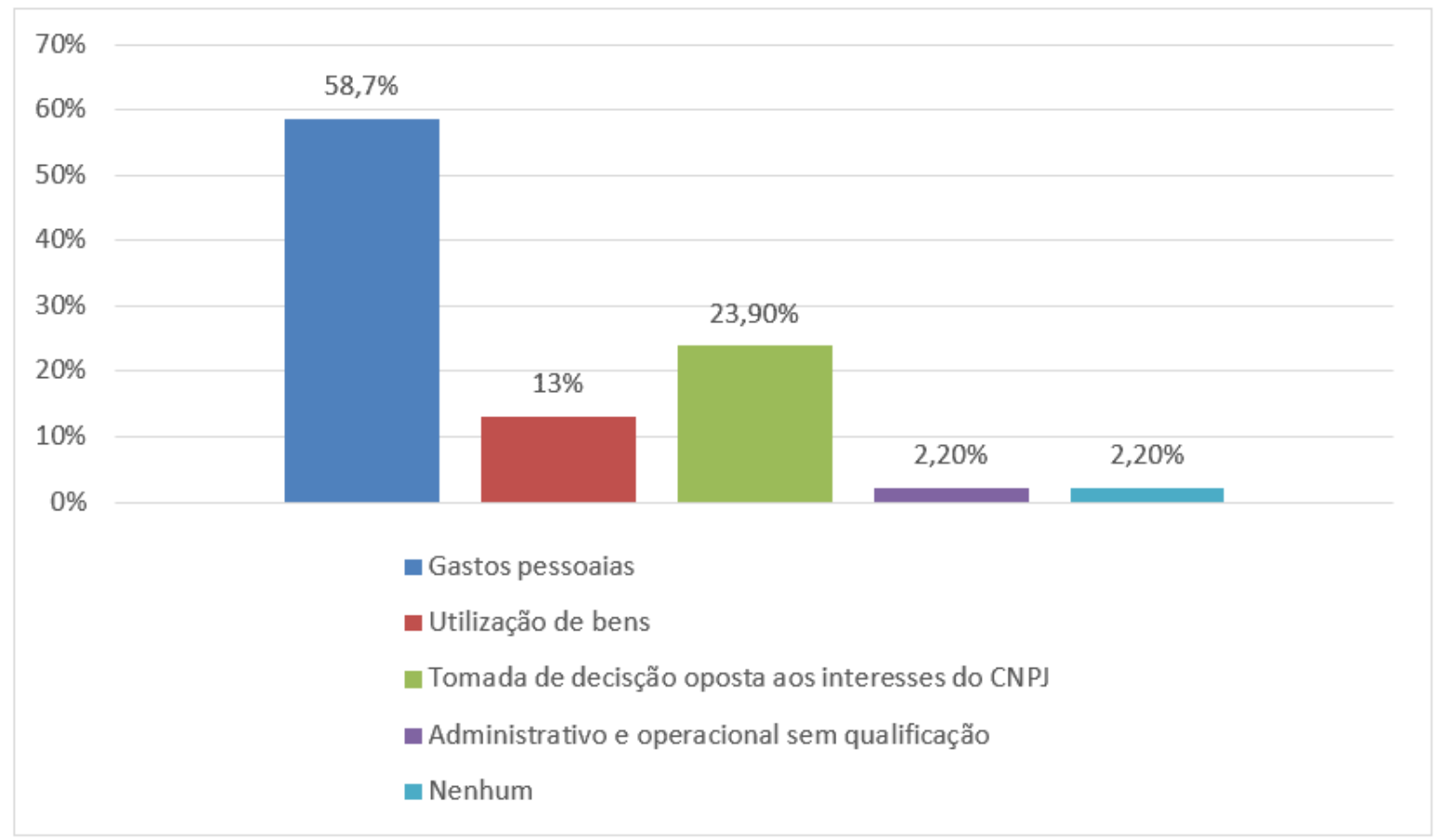

Fonte: Elaborado pela autora 
Os respondentes apontaram que os maiores desafios enfrentados foram os gastos pessoais (27 respostas ou $58,7 \%$ dos inquiridos) e tomada de decisão oposta aos interesses do CNPJ (11 respostas ou $23,90 \%$ dos inquiridos), evidenciando a falta de controle interno nas empresas. Para Rodrigues (2019, p.16), "os gestores preferem confundir o patrimônio, a ter que fazer a devida separação, pois seria um trabalho mais dispendioso".

Os resultados indicam a importância para a entidade do papel gerencial junto ao empreendedor nos desafios relacionados a administração e registro (KASSAI, 1997). Os estudos de Trago Attie (1998); Schmidt e Santos (2006); Müler e Beuren (2010); Perez e Hernandez (2011); Barbosa (2014); Almeida (2017); Crepaldi e Crepaldi (2017), concordam sobre a relevância do controle interno e ressaltam que este serve para verificar, regular as operações exercidas e alinhar a gestão das entidades.

Seis pesquisados $(13 \%)$ responderam que os maiores desafios enfrentados no que se refere à confusão patrimonial relaciona-se com a utilização de bens, um pesquisado $(2,20 \%)$ apontou o administrativo e operacional sem qualificação como desafio, e um pesquisado $(2,20 \%)$ pontuou que que nenhuma das alternativas apresentadas relacionam-se à Confusão Patrimonial.

Conclui-se a análise do item desafios da Confusão Patrimonial com um relato de experiência que envolve gastos pessoais e sonegação de tributos. Segundo o entrevistado,

Eu tive um caso marcante com uma empresa de reciclagem. O pessoal estava vendendo sem nota e botava o dinheiro na conta da pessoa física. Eu comecei a ver que a empresa começou a ter um prejuízo e as despesas maiores que a receita, então de onde vinha o dinheiro? É que ele pagava as contas particulares, não emitia nota fiscal, ele sonegava. Daí sempre dava prejuízo na empresa? Ele fazia isso pra não pagar imposto e ainda pagar as contas particulares Então eu orientei ele a tributar esses valores que ficaram como adiantamento ao sócio (a gente tem que ver a responsabilidade solidária do contador, que teria que responder por isso também) e fazer a distribuição de lucros (tudo que sobra, depois que tu pagou todas as contas da empresa, tu distribui entre os sócios da empresa), compensando as despesas particulares pagas pela empresa de cada sócio no período. O pior problema disso tudo é 
que ele prejudicou o desempenho na empresa porque todos achavam que ela nunca dava certo" (ENTREVISTADO 1).

Ressalta-se que o entrevistado finaliza sua fala com uma das consequências da confusão patrimonial que será analisada a seguir patrimonial. Veremos que o prejuízo no resultado financeiro é percebido pelos sujeitos da pesquisados como a principal consequência da confusão patrimonial.

Gráfico 7: Consequências da Confusão Patrimonial

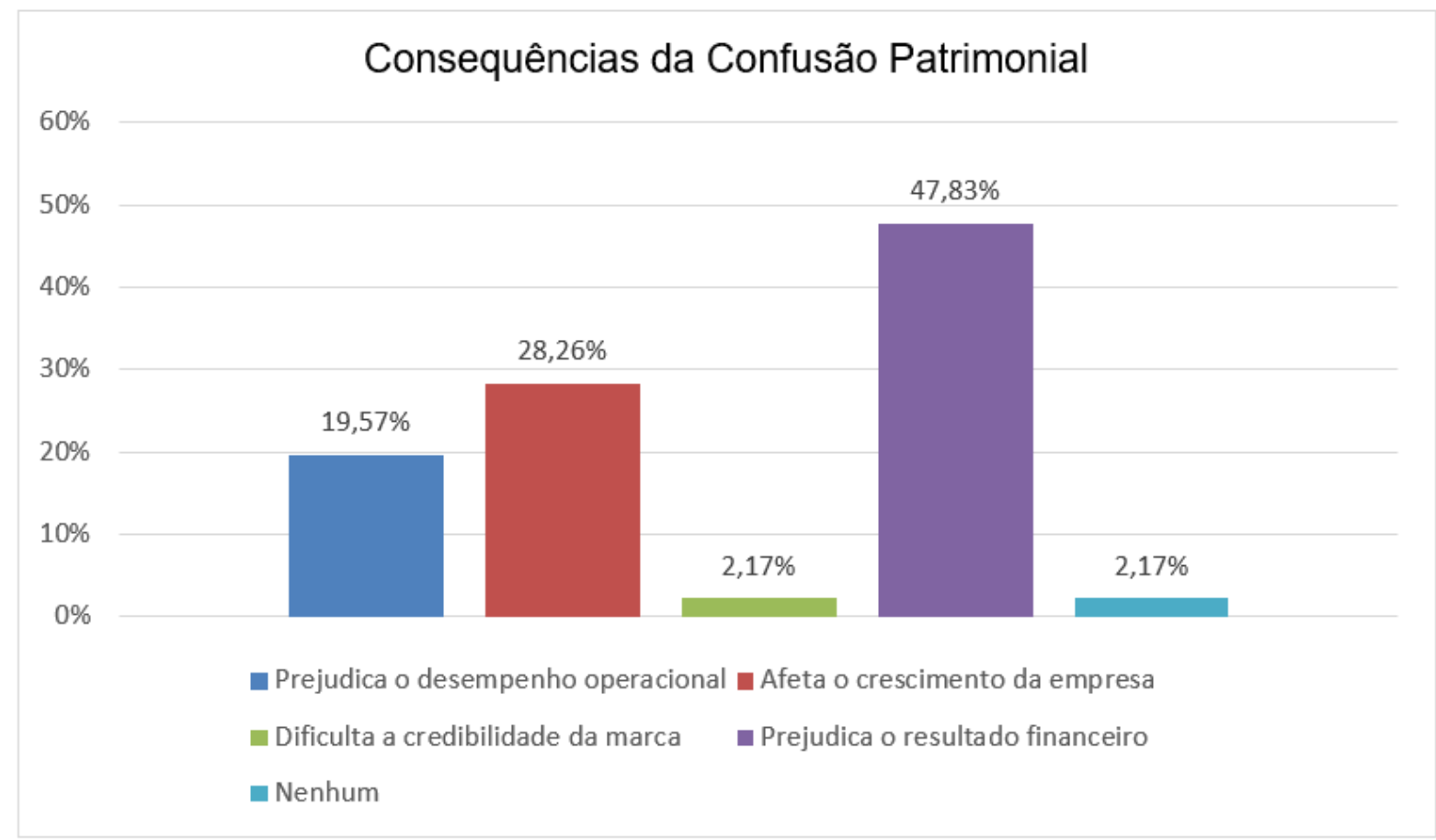

Fonte: Elaborado pela autora

A maioria dos respondentes percebem que a confusão patrimonial prejudica o resultado financeiro (22 respostas ou $47,83 \%$ dos inquiridos) e afetam o crescimento da empresa (13 respostas ou $28,26 \%$ dos inquiridos), demonstrando que a confusão patrimonial afeta a fidedignidade das demonstrações contábeis, sua realidade, a veracidade das informações e o crescimento da entidade. Pereira et al (2019) ressalta a importância de um sistema planejado de informações internas, considerando o mercado no qual a entidade está inserida para a tomada de decisões. 
Um dos prejuízos da confusão patrimonial destacados é do desempenho operacional (9 respostas ou 19,57\% dos inquiridos). Um dos entrevistados relatou um caso de uma empreendedora da área do turismo que pela confusão patrimonial prejudicou o resultado financeiro, o desempenho operacional e o crescimento da empresa. Este relato mostra que várias podem ser as consequências da confusão patrimonial ao mesmo tempo, em razão de problemas na gestão. Segundo o entrevistado,

a empreendedora e administradora não fazia uma gestão adequada e se atrapalhou no pagamento dos impostos. Ela não entendia por que os tributos estavam tão altos com relação a sua receita, contraindo dívidas e comprometendo o patrimônio dos sócios, então me contratou como auditor externo. Eu vi que o problema era a má gestão. Ela deveria enviar para a contabilidade notas somente com as comissões, mas ela enviava notas com comissões somadas a todas as outras despesas (de avião, de hotéis e prestadores de serviços). Atualmente ele está em um processo judicial se defendendo da cobrança da Receita Federal (ENTREVISTADO 2)

Como já foi desenvolvido neste estudo, um auditor externo é um profissional que não possui vínculo empregatício na empresa, pois é contratado para executar a auditoria contábil com a finalidade de realizar um estudo e construir um parecer atestando que as demonstrações financeiras correspondem ou não à situação patrimonial e financeira da empresa (Almeida, 2017; Cruz e Souza Junior, 2018; Silva, 2018). Por meio do parecer o contador solicita correções ao gestor e emite sugestões de melhoria para a empresa auditada (PEREIRA et al, 2019).

Por fim, um $(2,17 \%)$ respondente apontou que a confusão patrimonial dificulta a credibilidade da marca e um $(2,17 \%)$ inquirido não percebeu nenhuma consequência da confusão patrimonial.

\section{CONSIDERAÇÕES FINAIS}

O trabalho teve como objetivo principal investigar como os contadores e contabilistas do Rio Grande do Sul percebem a confusão patrimonial nas empresas. Para atender ao objetivo proposto, foram abordados: a confusão patrimonial nas empresas, os desafios enfrentados pelos contadores e contabilistas com relação à confusão 
patrimonial nas empresas nas quais prestam serviços e as consequências da confusão patrimonial na gestão financeira das empresas, na visão dos participantes da pesquisa.

A confusão patrimonial consiste num estado de desordem entre os patrimônios de duas ou mais pessoas, em que os patrimônios aparecem confundidos ou misturados. Foi constatado que surge principalmente a partir de gastos pessoais e desorganização com relação às despesas da entidade. Este fenômeno causa esgotamento patrimonial da sociedade devedora e o abuso na própria confusão de patrimônios entre sócio e sociedade ou entre sociedades integrantes do empreendimento.

A pesquisa evidenciou que a confusão patrimonial é corriqueira para os profissionais da área contábil, pois a maioria deles vivencia essa situação no exercício da profissão. As microempresas e empresas de pequeno e médio porte foram as que mais se destacaram nesta pesquisa. A pesquisa evidenciou que a confusão patrimonial se origina essencialmente pela ausência da gestão, pelo desconhecimento da legislação e pelo excesso de diretores. Demonstra, com isso, o desconhecimento e o despreparo dos gestores das entidades.

Constatou-se, com esta pesquisa, que os principais desafios da confusão patrimonial estão relacionados à falta gestão, falta de controle das operações e da utilização dos bens, prejudicando sobretudo o resultado da empresa e sua expansão no mercado.

Os profissionais da área contábil apontaram como principais consequências da confusão patrimonial a alteração do resultado financeiro e danos no crescimento e desempenho operacional. Porém a confusão patrimonial causa outros prejuízos à entidade, pois a realidades das demonstrações contábeis e as informações nelas contidas não condizem com a realidade da entidade, dificultando a tomada de decisão dos gestores.

Portanto este fenômeno corriqueiro e suas consequências nas empresas comprova que esta pesquisa é relevante. Resta dizer que este trabalho fomenta o debate sobre 
a confusão patrimonial, assunto ainda controverso no ordenamento jurídico pátrio e na área contábil.

O formulário Google construído para este trabalho foi disponibilizado no site do CRC/RS e foram enviadas mensagens por WhatsApp para aproximadamente 100 profissionais contábeis por acessibilidade. Contudo, apenas 46 indivíduos responderam o questionário. Acredita-se que o tamanho da amostra (limitação deste trabalho) foi influenciado pelo contexto de Pandemia no primeiro semestre de 2020. Vários foram os problemas enfrentados neste contexto, ressaltados, inclusive, pelos entrevistados: tempo para responder o questionário devido os decretos e revogações na legislação, situação das empresas que tiveram que encerrar suas atividades e o estado de pavor da população.

Como sugestões de pesquisas futuras, recomenda-se pesquisar soluções para a confusão patrimonial nas empresas, dando um enfoque na área jurídica. Os pesquisadores podem, com isso, se aprofundar no levantamento e no cruzamento de dados da origem/causa e consequência da confusão patrimonial. Também pode ser realizada uma análise comparativa entre confusão patrimonial nas empresas de pequeno e médio porte com as empresas de grande porte no Rio Grande do Sul.

Por fim, que este trabalho possa servir para a compreensão da confusão patrimonial, que causa diversos prejuízos para as empresas. Que sirva, também, como estímulo para novas pesquisas sobre o tema.

\section{REFERÊNCIAS}

ALMEIDA, Marcelo Cavalcanti. Auditoria: abordagem moderna e completa. 9. Ed. São Paulo: Atlas, 2017.

AQUINO, Leonardo. Conceito de empresa. In. Estado de Direito: informação formando opinião. Porto Alegre, 2017. Disponível em: http://estadodedireito.com.br/conceito-de-empresa/ Acesso em: 15 de março de 2020. 
ASCOM/ANVISA. Porte de empresas: esclareça todas as suas dúvidas. ANVISA: Brasília, 2019. Disponível em: http://portal.anvisa.gov.br/noticias//asset_publisher/FXrpx9qY7FbU/content/porte-de-empresas-esclareca-todas-assuas-duvidas/219201 Acesso em: 04 de abril de 2020.

BARBOSA, T. A. M. Os sistemas de controles internos utilizados nas contas a receber das empresas de comércio de autopeças: o caso da empresa Eletropel Distribuidora de Autopeças LTDA. Trabalho de Conclusão de Curso (Graduação em Ciências Contábeis), Universidade Federal de Goiás, Goiás, 2014.

BARDIN, Laurence. Análise de Conteúdo. Lisboa: Edições 70, 1977.

BRASIL. LEI N. 10.406. Institui o Código Civil. Brasília, 2002. Disponível em: http://www.planalto.gov.br/ccivil_03/leis/2002//10406.htm Acesso em: 29 de Setembro de 2019.

BRASIL. LEI № 13.874. Institui a Declaração de Direitos de Liberdade Econômica; estabelece garantias de livre mercado; altera as Leis nos 10.406, de 10 de janeiro de 2002 (Código Civil), 6.404, de 15 de dezembro de 1976, 11.598, de 3 de dezembro de 2007, 12.682, de 9 de julho de 2012, 6.015, de 31 de dezembro de 1973, 10.522, de 19 de julho de 2002, 8.934, de 18 de novembro 1994, o Decreto-Lei o 9.760, de 5 de setembro de 1946 e a Consolidação das Leis do Trabalho, aprovada pelo Decreto-Lei № 5.452, de 1ํ de maio de 1943; revoga a Lei Delegada oㅡ 4, de 26 de setembro de 1962, a Lei no 11.887, de 24 de dezembro de 2008, e dispositivos do Decreto-Lei no 73, de 21 de novembro de 1966; e dá outras providências. Brasilia, DF, 2019.

CERVO, Amado Luiz; BERVIAN, Pedro Alcino; DA SILVA, Roberto. Metodologia científica. São Paulo: Pearson Prentice Hall, 2007.

CONSELHO FEDERAL DE CONTABILIDADE. Princípios Fundamentais da Contabilidade - Resolução CFC no 750/93. Brasília: CFC, 1993.

CREPALDI, Aparecido; CREPALDI, Simões. Auditoria Contábil: teoria e prática. 10. Ed. São Paulo: Atlas, 2017. 
CRUZ, C. F.; SOUSA JÚNIOR, A. B. Atividade de auditoria contábil: um enfoque teórico de sua aplicação em empresas. Entrepreneurship, v.2, n.2, p.1-16, 2018. Disponível: < http://doi.org/10.6008/CBPC2595- 4318.2018.002.0001 >. Acesso em: 10 de outubro de 2019.

CUNHA, Kaio. Saiba como definir o porte da empresa e no que isso pode impactar o negócio. CONUBE: São Paulo, 2018. Disponível em: https://conube.com.br/blog/como-definir-o-porte-da-empresa/ Acesso em: 01 de abril de 2020.

DIÁRIO DO COMÉRCIO. MPEs respondem por $\mathbf{3 0} \%$ do PIB brasileiro. AbrasBrasil, 2020.

Disponível

em:

<https://www.abras.com.br/clipping.php?area=2\&clipping=70471> Acesso em: 03 de jun de 2020.

DRUCKER, Peter. 0 melhor de Peter Floriani Drucker: a administração. São Paulo: Nobel, 2001.

GERHARDT, Tatiana Engel; SILVEIRA, Denise Tolfo (Org.). Métodos de pesquisa. Porto Alegre: Ed. da UFRGS, 2009. (Educação a Distância, 5).

GIL. Antonio Carlos. Métodos e técnicas de pesquisa social. São Paulo: Atlas, 2008.

KASSAI, Silvia. As empresas de pequeno porte e a contabilidade. Caderno de estudos. São Paulo, n. 15, p. 01-23, 1997. Disponível

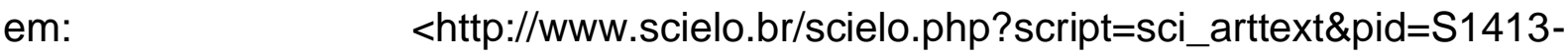
92511997000100004\&lng=en\&nrm=iso >. Acesso em: 10 de março de 2020.

MARCONI, Mariana; LAKATOS, Eva. Fundamentos de Metodologia científica. São Paulo: Atlas, 2010. 
MINAYO, Maria Cecília de Souza. O desafio da pesquisa social. In: MINAYO, Maria Cecília de Souza; GOMES, Suely Ferreira Deslandes Romeu (orgs.).Pesquisa social: teoria, método e criatividade. $27^{a}$ ed. Petrópolis: Vozes, 2008.

MÜLER, Elza Terezinha Cordeiro; BEUREN, Ilse Maria. Estrutura formal e práticas da controladoria em empresas familiares brasileiras. Gestão \& Regionalidade Vol. $26 \quad$ - $20 \quad 76 \quad$-jan-abr/2010. Disponível em: http://seer.uscs.edu.br/index.php/revista_gestao/article/view/177 Acesso em: 20 de setembro de 2019.

PEREIRA, Aluisio et al. Os impactos da controladoria e finanças dentro da auditoria organizacional. RRCF, Fortaleza, v.10, n.2, jul/. 2019. Disponível em: http://institutoateneu.com.br/ojs/index.php/RRCF/article/view/220/233 Acesso em: 05 de outubro de 2019.

PEREIRA, Paulo. Microempresa, Empresa de Pequeno Porte e Microempreendedor Individual: diferenças e características. SEBRAE: Santa Catarina, 2019. Disponível em: https://blog.sebrae-sc.com.br/epp-microempresa-mei/ Acesso em: 02 de abril de 2020.

PEREZ, J.; HERNANDEZ, J. H. Auditoria de Demonstrações Contábeis: normas e procedimentos, 5. ed. Atlas, 2011.

PEREZ JUNIOR, José Hernandez et al. Auditoria das demonstrações contábeis. 2. Ed. Rio de Janeiro: Editora FGV, 2011.

RIOS, Jose; PEREIRA, Humberto. A controladoria nas pequenas empresas e microempresas. Ciências gerenciais em foco, v. 9, n. 6, MG: UEMG, 2018. P. 65 83.

RODRIGUES, Igor Pereira. Confusão patrimonial em empresa famíliar: estudo de caso de uma rede de supermercados em Uberlândia. 2019. 28 f. Trabalho de Conclusão de Curso (Graduação em Ciências Contábeis) - Universidade Federal de Uberlândia, Uberlândia, 2019. 
SCHMIDT, Paulo, SANTOS, José L. Fundamentos de Controladoria. São Paulo: Atlas, 2006.

SEBRAE - Serviço Brasileiro de Apoio às Micro e Pequenas Empresas. Empresas familiares assumem liderança de mercado. SEBRAE, 2019. Disponível em: https://exame.abril.com.br/negocios/dino/empresas-familiares-assumem-liderancade-mercado/ Acesso em: 10 de outubro de 2019.

SARTORI, Guilherme. As necessidades de controles internos dos empreendimentos de pequeno e médio porte na cidade de ljui e as contribuições do profissional de contabilidade. Trabalho de Conclusão de Curso (Especialização em Controladoria e Gestão Empresarial). Unijuí: ljuí, 18p, 2018.

SEBRAE - Serviço Brasileiro de Apoio às Micro e Pequenas Empresas Relatório especial: Empresas Familiares. SEBRAE, 2015. Disponível em: http://www.bibliotecas.sebrae.com.br/chronus/ARQUIVOS CHRONUS/bds/bds.nsf/d b16fac96aa7a4f7f1b8af2dc5e000a1/\$File/5986.pdf Acesso em: 12 de Abril de 2020.

SILVA, André Luiz. Governança corporativa e decisões financeiras no Brasil. Rio de Janeiro: Mauad, 2005.

SILVA, Edson Colar da. Auditoria Fiscal: Apoio na Gestão de Empresas Prestadoras de Serviços. 2018. Número total de folhas. Trabalho de Conclusão de Curso em Ciências Contábeis - Faculdade Anhanguera Educacional, Sumaré-SP 2018. Disponível

em: <file:///C:/Users/XPS/Downloads/Edson\%20Colar\%20da\%20Silva\%20(1).pdf>. Acesso em: 10 de outubro de 2019.

TRIVIÑOS, A. N. S. Introdução à pesquisa em ciências sociais: a pesquisa qualitativa em educação. São Paulo: Atlas, 1987.

VOLTZ, Juliana; AYDOS, Mariana. Gestão e Sucessão em Empresas Familiares de Pequeno Porte em Porto Alegre. Anais do IX Congresso Brasileiro de Administração e Contabilidade - AdCont 2018. RJ: UNIRIO, 2018. p. 1-16 


\section{APÊNDICE A - FORMULÁRIO GOOGLE}

\section{CONFUSÃO PATRIMONIAL NAS EMPRESAS}

Você está sendo convidado(a) como voluntário(a) a participar da pesquisa para o trabalho de conclusão do curso de bacharelado em Ciências Contábeis da estudante Juliana Voltz, pela Faculdade Senac Porto Alegre. O objetivo da pesquisa é investigar a percepção dos contadores e contabilistas do Rio Grande do Sul sobre a confusão patrimonial nas empresas de pequeno e médio porte. Para tanto, peço que responda às seguintes perguntas.

Com quantos clientes (CNPJ) você trabalha como contador/contabilista?

Até 50

50 a 100

100 a 200

200 a 300

Acima de 300 
Você percebe confusão patrimonial nas empresas com as quais trabalha?

$\operatorname{Sim}$

Não

$\because$

Se a resposta anterior for positiva, qual o percentual de empresas que apresentaconfusão patrimonial?

Até $20 \%$

Entre $20 \%$ e $30 \%$

Entre $30 \%$ e $50 \%$

Entre $50 \%$ e $80 \%$

Acima de $80 \%$

Qual a origem da confusão patrimonial nas empresas?

Desconhecimento da legislação

Ausência de gestão

Excessos de diretores

Outros... 
Qual o porte das empresas que apresentam confusão patrimonial?
Microempresa
Pequeno porte
Médio porte
Grande Porte

Quais foram os principais desafios que enfrentou com relação a confusão patrimonial?

Gastos pessoais

Utilização de bens

Tomada de decisão oposta aos interesses do CNPJ

Outros..

$\because:$

Quais são as principais consequências da confusão patrimonial na gestão das empresas?

Prejudica o desempenho operacional

Afeta o crescimento da empresa

Dificulta a credibilidade da marca

Prejudica o resultado financeiro

Outros.

\section{APÊNDICE B - ROTEIRO DE ENTREVISTAS}

1. Você já enfrentou questões que envolviam confusão patrimonial em alguma empresa com a qual você já trabalhou como contador-contabilista? 
2. Você poderia relatar alguma experiência?

3. Como você lidou com a experiência?

\section{APÊNDICE C - REFERÊNCIA DE NOTA DE RODAPÉ}

2. De acordo com Gil (2008) há três tipos de questão: fechadas, abertas e dependentes. Nas questões abertas pede-se aos investigados que apresentem suas próprias respostas; nas questões fechadas, pede-se que o respondente escolha a alternativa em uma lista; e nas questões dependentes, após uma determinada alternativa é escrito o procedimento a ser seguido pelo respondente.

Enviado: Julho, 2020.

Aprovado: Agosto, 2020. 